\title{
The Analysis of Green School Program Impact on Environmental Management Behavior and Psychology of High School Students in Jakarta
}

\author{
Haris Mukti Amrullah ${ }^{1}$, Herdis Herdiansyah ${ }^{2}$ \\ \{ais_amru@yahoo.co.id ${ }^{1}$, herdis@ui.ac.id ${ }^{2}$ \} \\ School of Environmental Science, Universitas Indonesia, Jl. Salemba Raya No. 4, Jakarta, \\ Indonesia $^{1,2}$
}

\begin{abstract}
As the next generation, high school students receive teaching and habituation about behavior towards the environment. The form of habituation of environmental management behavior is done through various programs, one of which is Green School. Green School encourages all school residents to get used to eco-friendly behavior. This research raises the issue of the impact of the Green School program on students' environmental behavior. The form of participation and behavior of environmental management are also described in this study. The method used is a survey using the proenvironmental behavior instrument among high school students in the school. The results indicate that the environmental behavior of high school students is still in the medium category, which means that environmentally friendly behavior among high school students has not been accustomed. Besides, the impact of the Green School program has not been fully able to familiarise students with environmentally friendly behaviors.
\end{abstract}

Keywords: Environmental management behavior, participation, high school students, Green School.

\section{Introduction}

Environmental changes have been a crucial issue frequently discussed in society nowadays. Various natural phenomena and disasters that occur make people aware of the importance of maintaining the environment. To protect the environment, the community is often faced with the problem of lack of knowledge to manage a pleasant atmosphere. One of the places where formal education should teach environmental management is the school. The school environment can be one of the learning media used to teach environmental education[1]. As an educational institution, a school is a place of student character and behavior formation. The establishment of an environmentally-friendly student character in school becomes an important thing to do to protect the environment. Environmental education can be a means of education and formal delivery of eco-friendly behavior. According to UNESCO, environmental education in schools has several objectives, such as raising environmental awareness, providing an opportunity for everyone to gain ecological knowledge and shaping eco-friendly behavior in the community[2]. Environmental education at school is at least two things, one on curriculum that incorporates environmental value and another is an extra-curricular organization[3].

One of the programs that shape environmental behavior as part of environmental education is the Green School. Green School is a program aimed at developing the character of 
schoolchildren who are responsible for the management and conservation of the environment through good school governance that supports sustainable environmental management[4]. The existence of the Green School program became the support in the enactment of environmentally friendly behavior, especially for the school people. Support in the form of environmentally friendly programs and policies is one of the factors driving people to be environmentally friendly[5].

The Green School program at the school is conducted through an environment-based school management policy involving all members of the school, especially students. The policy of habituating environmental behavior in schools is expected to be implemented in the daily life of the students. Students who have a sense of attachment to their school can be influenced by their natural behavior through policy and habituation at school[6]. The green school program is characterized by a curriculum that is integrated with environmental activities, with studentcentered learning that empowers the students to be active, creative and innovative with various activities that preserve school environment[7].

Environmental behavior can be driven by cultural and habitual factors that develop both in person and community[8]. Habits that emerge in society will be imitated by individuals and become their daily behavior. Habituation of environmental behavior in society will be able to encourage other individuals to behave in the same manner. The habituation of good environmental behavior in school will encourage students to act the same in their daily life. The existence of this support factor will be able to motivate students to behave environmentally friendly.

Based on the theory of behavior formation [9] eco-friendly behavior emergence is preceded by the existence of environmental concerns. Then efforts to respond to these concerns transpire, which will then bring the values and norms that developed in the community and a guide for people in behaving. So is the behavior of high school students who appear along with environmental policies in schools in response to concerns about environmental damage. Some of the responses are related to environmental concerns with the efficiency of resource use and waste minimization[10]. Associated with the reaction, the Green School program emphasizes the efficiency of behavior and concept of waste recycling in schools. The program is in the form of garbage bank procurement, the efficiency of electricity and water, and processing of organic waste independently by the school. Changes in environmental understanding among learners are adopted in various policies, such as the management of eco-friendly parking, environmentally friendly libraries, and others. Today, now not only in formal schools, but environmental awareness has also now been implemented in non-formal education such as pesantren who started to practice eco pesantren[11]. All programs must be performed by all citizens of the school, either teacher, employees, or students as a form of habituation to behave environment. Teachers play an essential role in every school run program, mainly related to this Green School [12]. However, this program still has some weaknesses. These include the fact that this program was a participatory-based activity, which means not all students, teachers and school employees are aware of the program [13]. Another weakness is not all lessons plan in this school has been conducted in line with the program.

Based on the description, we can formulate a research question on whether the Green School Program can positively influence students' environmental behavior and how effective the implementation of the Green School Program is. In this research, we will analyze to what extent the Green School program is effective in supporting the student's environmental behavior in everyday life. This research aims to evaluate the Green School Program and its impact on students' environmental behavior. The form of participation and response gave by the students will be analyzed using a quantitative approach through a survey using the Green School Program 
assessment. The student's daily behavior is then analyzed using descriptive statistic method. We also use direct observation to describe how the Green School Program is implemented in the school. Measuring students' environmental behavior is important because it reflects whether the programs have been running so far are effective or not in shaping the students' environmental behavior. Also, this research will be an evaluation material for the program that has been running as well as content for the planned programs related to the formation of student character that is environmentally friendly.

\section{Methodology}

The study was conducted in SMA X Jakarta, involving 100 respondents from 11 th-grade students who attended school there. The 11th graders were chosen as respondents because students at this level are more involved in school programs than students in another grade level, so the effectiveness of the program can be measured well in grade 11 students. Environment behavioral data was measured using environmental awareness aspect, environment, the participation in environmental protection, environmental management and attention to environmental issues. Further survey results were analyzed by descriptive statistical analysis method to explain the level of students' environmental behavior. Ongoing Green School program data was taken by direct observation and student assessment involving participation, creativity, awareness, and others in the Green School program. Also, a literature study was also conducted to find out what applications are running. The results of observations on the Green School program are then analyzed concerning the environmental behavior that is formed on the students. The analysis correlation between Green School Program and Environmental Behavior is using SPSS 22.0. To find out the effectiveness of the Green School Program in the school, direct observation is used in some activities related to the program such as garbage bank, greening program, and energy efficiency program. So it will be known how the effectiveness of Green School programs that run in SMA in shaping the character of students.

\section{Results and Discussion}

The result of the measurement of students' environmental behavior shows that most of the respondents are demonstrating good behavior. Some indicators to measure environmental behavior include students' everyday behavior, especially that demonstrated in the program, such as littering behavior (whether students follow the 3R principle or not), energy using behavior (efficient or not), house greening, and participation in preserving the environment [14]. Based on the result of the grouping of environmentally sound behavior, it is seen that high school students tend to act pro-environment[15]. Knowledge gained on environmental issues in learning shapes students' environmentally sound behavior. Knowledge of the existence of the issue becomes one of the conditions in the formation of environmentally sound behavior[16]. The behavior that is formed on the students is related to the habituation of environmental behavior that is held in Green School's policies at the school. The knowledge that has been provided in schools plus the support of the provision of facilities to behave environmentally friendly in schools shape the character of students to be more environmentally friendly[17]. However, not all students can demonstrate environmentally sound behavior in everyday life. This is reflected in the survey results which show that the students' environmental behavior is 
an insufficient category, which means that not all students familiar with environmentally friendly behavior.

Based on the environmentally sound behavior measurement, we classified the students into five groups according to the extent of their environmentally sound behavior, namely very good, good, fair, bad and very bad. From 100 respondents, only 1 person falls into the category of very good. Respondents who demonstrate good behavior consist of 42 persons, while 55 falls into the fair category. On the other hand, the respondents belonging to the bad category are as many as 2 people, and no respondents are in the very bad category. The distribution of categories of environmentally sound behavior and assessment result scores can be seen in Table 1.

Table 1. Distribution of green school assessment result and environmentally sound behavior.

\begin{tabular}{|c|c|c|c|c|}
\hline \multirow{3}{*}{$\begin{array}{c}\text { Environmentally Sound } \\
\text { Behavior }\end{array}$} & \multicolumn{4}{|c|}{ Green School Assessment Result } \\
\hline & \multicolumn{2}{|c|}{ Pass } & \multicolumn{2}{|c|}{ Fail } \\
\hline & $\mathrm{N}$ & $\%$ & $\mathrm{n}$ & $\%$ \\
\hline Very Good & 1 & 1,2 & 0 & 0,0 \\
\hline Good & 39 & 45,9 & 3 & 20.0 \\
\hline Fair & 43 & 50,6 & 12 & 80,0 \\
\hline $\mathrm{Bad}$ & 2 & 2,4 & 0 & 0,0 \\
\hline Very Bad & 0 & 0,0 & 0 & 0,0 \\
\hline Total & 85 & 100 & 15 & 100 \\
\hline
\end{tabular}

Based on the correlation table, it can be seen that the Green School Program variable and students' environmental behavior has no significant relationship with the correlation value (.089). It means that the Green School Program is not a significant predictor of student's environmental behavior.

Table 2. Correlation between green school program and environmental behavior*.

\begin{tabular}{|c|c|c|c|}
\hline & & $\begin{array}{c}\text { Green School } \\
\text { Program } \\
\end{array}$ & $\begin{array}{c}\text { Environmental } \\
\text { Behavior }\end{array}$ \\
\hline \multirow{3}{*}{$\begin{array}{l}\text { Green School } \\
\text { Program }\end{array}$} & Pearson Correlation & 1 & 0,089 \\
\hline & Sig (2-tailed) & & 0,380 \\
\hline & $\mathrm{N}$ & 100 & 100 \\
\hline \multirow{3}{*}{$\begin{array}{c}\text { Environmental } \\
\text { Behavior }\end{array}$} & Pearson Correlation & 0,089 & 1 \\
\hline & Sig (2-tailed) & 0,380 & \\
\hline & $\mathrm{N}$ & 100 & 100 \\
\hline
\end{tabular}

Environmental behavior is formed by internal, external and psychological factors mixed to form behavior. Environmental behavior is also situational, hence if there is a change of situation then behavior can also change[18].

The many other factors and the nature of this situational environmental behavior may be the cause of the low contribution of the program to environmentally sound behavior. Environmental-minded behavior is also influenced by other factors that support individuals to act. Individual behavior on the environment requires not only the factor forming behavior, but also a suitable condition[5].

The Green School programs implemented in schools are carried out by conducting various forms of environmental conservation, especially those related to afforestation, application of the $3 \mathrm{R}$ principles and the application of energy efficiency. This result is following research on green 
school which in majority still emphasize on the use of the greening program, recycling, and energy efficiency[19]. Some programs that have been implemented in order to run Green School in schools include The Garbage Bank Program (program is conducted in every class by collecting the remaining unused items, mainly plastic and students' water bottles, etc), Greening Program (programs are done by providing plants in every aisle and park maintenance, etc), Resource Efficiency Program (y program is carried out with electricity savings in every room. Every student is responsible for the electricity savings in each class, by minimizing the use of lights and turning off appliances that are not used).

\section{Conclusions}

The Green School Program conducted at school is not able to significantly enhance students' environmental behavior in their daily lives. A program implementation strategy, along with the at school habituation for students, is needed for the fundamental objectives of the Green School program to be achieved. Thus, the character of students who care about the environment around them and implement it in their daily lives will be formed. Future work related to this research should aim to find out other factors which can improve student environmental behavior and recommend programs which can be more effective in improving students' environmentally sound behavior.

Acknowledgments. This work is supported by Hibah PITTA 2018 funded by DRPM Universitas Indonesia No. 2577/UN2.R3.1/HKP.05.00/2018.

\section{References}

[1] Kong, S.Y., Rao, S.P., Abdul-Rahman, H., Wang, C.: School as 3-D textbook for environmental education: Design model transforming physical environment to knowledge transmission instrument. Asia-Pacific Educ. Res., vol. 23, no. 1, pp. 1-15 (2014)

[2] Stevenson, R.B., Brody, M., Dillon, J., Wals, A.E.J.: International handbook of research on environmental education. Routledge (2013)

[3] Sureda, J., Calvo, A.M.: Organization of school centres and environmental education: In search of action models for the greening of school organization. Environmentalist, vol. 21, no. 4, pp. 287-296 (2001)

[4] Meyer, A.: Does education increase pro-environmental behavior? Evidence from Europe. Ecol. Econ., vol. 116, pp. 108-121 (2015)

[5] Manning, C.: The psychology of sustainable behavior. St. Paul, MN Minnesota State Pollut. Control Agency (2009)

[6] Rufaedah, A.: Influence of Five Types of Ecological Attachments on General Pro-Environmental Behavior. Procedia-Social Behav. Sci., vol. 85, pp. 535-543 (2013)

[7] O'Brien, C., Howard, P.: The living school: The emergence of a transformative sustainability education paradigm. J. Educ. Sustain. Dev., vol. 10, no. 1, pp. 115-130 (2016)

[8] Rao, I.: Work-life balance for sustainable human development: Cultural intelligence as enabler. J. Hum. Behav. Soc. Environ., vol. 27, no. 7, pp. 706-713 (2017)

[9] Stern, P.C., Dietz, T., Abel, T., Guagnano, G.A., Kalof, L.: A value-belief-norm theory of support for social movements: The case of environmentalism. Hum. Ecol. Rev., pp. 81-97 (1999) 
[10] Choudri, B.S., Baawain, M., Al-Zeidi, K., Al-Nofli, H., Al-Busaidi, R., Al-Fazari, K.: Citizen perception on environmental responsibility of the corporate sector in rural areas. Environ. Dev. Sustain., vol. 19, no. 6, pp. 2565-2576 (2017)

[11] Herdiansyah, H., Jokopitoyo, T., Munir, A.: Environmental awareness to realizing green Islamic boarding school (Eco-Pesantren) in Indonesia. IOP Conf. Ser. Earth Environ. Sci., vol. 30, no. 1, pp. 12017 (2016)

[12] Kennedy, K.J., Chow, J.K.F.: Schooling's contribution to a sustainable future in Asia: Can schools develop 'green'citizens? Ski. Dev. Incl. Sustain. Growth Dev. Asia-Pacific, pp. 345-365 (2013)

[13] Warju, S.P.H., Soenarto, M.D.H.: Evaluating the Implementation of Green School (Adiwiyata) Program: Evidence from Indonesia. Int. J. Environ. Sci. Educ., (2017)

[14] Dolnicar, S., Grün, B.: Environmentally friendly behavior: Can heterogeneity among individuals and contexts/environments be harvested for improved sustainable management? Environ. Behav., vol. 41, no. 5, pp. 693-714 (2009)

[15] Levine, D.S., Strube, M.J.: Environmental attitudes, knowledge, intentions and behaviors among college students. J. Soc. Psychol., vol. 152, no. 3, pp. 308-326 (2012)

[16] Sobur, A.: General Psychology. Pustaka Setia, Bandung (2009)

[17] Jensen, B.B.: Knowledge, action and pro-environmental behaviour. Environ. Educ. Res., vol. 8, no. 3, pp. 325-334 (2002)

[18] Putrawan, I.M.: Ecological Concepts in Environmental Activities. Alfabeta, Bandung (2014)

[19] Somwaru, L.: The Green School: a sustainable approach towards environmental education: Case study. Brazilian J. Sci. Technol., vol. 3, no. 1, pp. 10 (2016) 